J.Japan. Assoc, Min.

Petr. Econ. Geol.

70, 305-314, 1975

\title{
MINERAL PARAGENESES OF ARGILLACEOUS XENOLITHS IN ANDESITIC ROCKS FROM THE NIJO-SAN AND AMATAKI-YAMA DISTRICTS, SOUTHWEST JAPAN
}

\author{
MichIO TAgrRI \\ Department of Geology, Ibaraki University, Mito \\ HitoshI ONUKI \\ Institute of Mineralogy, Petrology and Econamic Geology, Tohoku University, Sendai \\ TeIJI YamazakI \\ Institute of Earth Science, Osaka Kyoiku University, Osaka
}

\begin{abstract}
The argillaceous xenoliths within the andesitic lavas of the Nijo-san and Amatakiyama districts were recrystallized successively by the thermal effects of the magma. The mineral assemblages of these xenoliths can be classified into the large-grained and fine-grained groups. The former is subdivided into the staurolite-bearing and staurolitefree assemblages. The staurolite-bearing parageneses of the minerals can be regarded as the amphibolite or pyroxene hornfels facies and the stauro lite-free ones composed of minerals with large grain-size belong to the pyroxene hornfels facies. Such fine-grained parageneses as the corona texture and the breakdown products of garnet were formed under the conditions of the pyroxene hornfels or sanidinite facies. From the progressive change of mineral facies and the distinct descrepancy of grain-size between the large mineral assemblages and fine mineral ones, it is possible to consider, roughly estimating, that the former indicates the stage of contact metamorphism and the latter the stage of pyrometamorphism.
\end{abstract}

\section{INTRODUCTION}

Since the early part of this century, the xenolithic inclusions in the andesitic rocks of the Nijo-san and Amataki-yama districts have been well known for the occurrences of staurolite, garnet, sillimanite, andalusite and corundum. Petrological studies on the volcanic rocks of these districts that are situated in the Setouchi (Inland Sea) Petrographic Province were made by Kozu and Yagi (1941), Takeuchi (1941), Morimoto et al. (1953), Morimoto, Fuzita and Kasama (1957), Yamazaki and Onuki (1969), Kato et al. (1971), Ujike (1972) and Yamazaki et al. (1973). The andesitic rocks erupted during the age from Late Miocene to Early Pliocene. The granitic rocks and metamorphic rocks as the basements of these districts belong to the Ryoke metamorphic terrane that was subjected to the low pressure series of metamorphism. The metamorphic rocks are characterized by pelitic schists and gneisses.

$U_{p}$ to this time, staurolite-bearing rocks in Japan, except the districts mentioned above, occur in the Unazuki district of the Hida metamorphic belt (Ishioka and Suwa, 1956), the Furudono, Takabo-yama and 

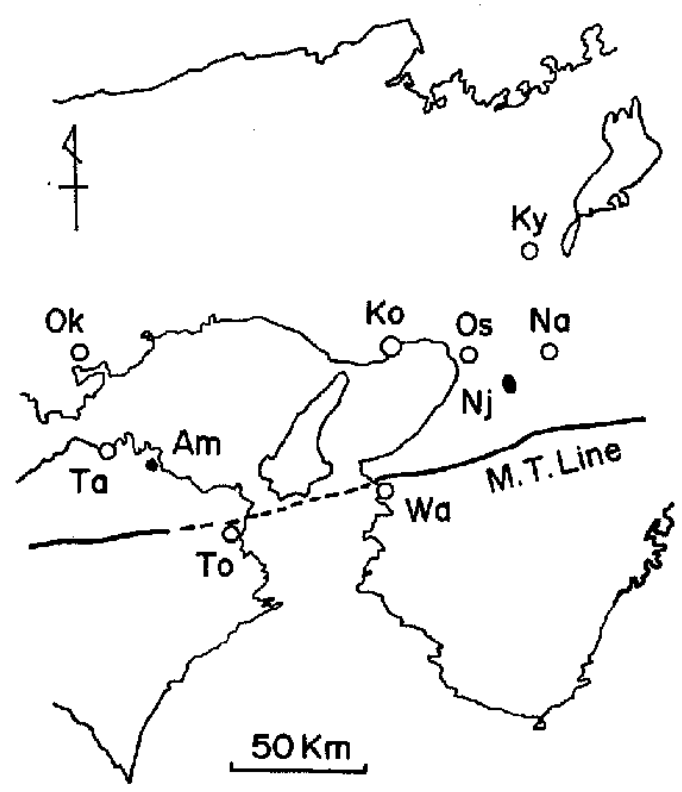

Fig. 1. Index map of the Nijo-san and Amataki-yama districts.

Am : Amataki-yama, Ko: Kobe, Ky : Kyoto, $\mathrm{Na}$ : Nara, $\mathrm{Nj}$ : Nijo-san, Ok: Okayama, Os: Osaka, Ta: Takamatsu, To: Tokushima, Wa ; Wakayama, M.T. Line: Median tectonic line.

Nishidohira districts of the Abukuma metamorphic belt (Uruno and Kanisawa, 1965; Research Group of the Abukuma Plateau, 1969; Tagiri, 1971), and the Hazu district of the Ryoke metamorphic belt (Asami, 1971). The staurolites of the Unazuki and Nishidohira districts coexist with kyanite, andalusite, sillmanite and garnet. The others associate with andalusite, sillimanite, spinel and corundum. From their geological environment these saturolite-bearing rocks are contradistinguished from those of the Nijo-san and Amataki-yama districts.

The xenoliths from the two districts have been interpreted as the fragments of the older metamorphic rocks prior to the Ryoke metamorphism or of the deeper part of the Ryoke metamorphic rocks (Miyashiro,
1965). These xenoliths are described with reference to the mineral parageneses and discussions are presented on the metamorphic conditions of these xenoliths.

\section{Brief Description on the ANDe- SITIC Rocks}

The xenolith-bearing andesitic rocks of the two districts mentioned above are of the calc-alkali rock series (Morimoto, Fuzita and Kasama, 1957).

The xenolith-bearing garnet biotite andesite lava in the Nijo-san district consists of phenocrystic plagioclase ( $\mathrm{An}=$ 64-45), biotite, garnet and quartz, and its groundmass minerals are plagioclase, orthopyroxene, clinopyroxene, iron ores, apatite, cristobalite and glass. This andesite contains garnet, biotite, plagioclase, quartz

Table 1. Chemical compositions of the xenolithbearing andesitic rocks.

\begin{tabular}{|l||r|r|}
\hline & \multicolumn{1}{|c|}{1} & \multicolumn{1}{c|}{2} \\
\hline $\mathrm{SiO}_{2}$ & 61.67 & 57.57 \\
$\mathrm{TiO}_{2}$ & 0.60 & 0.97 \\
$\mathrm{Al}_{2} \mathrm{O}_{3}$ & 17.92 & 17.78 \\
$\mathrm{Fe}_{2} \mathrm{O}_{3}$ & 0.41 & 1.58 \\
$\mathrm{Fe} 0$ & 3.91 & 3.96 \\
$\mathrm{MnO}$ & 0.11 & 0.13 \\
$\mathrm{MgO}$ & 1.52 & 2.79 \\
$\mathrm{CaO}$ & 4.77 & 5.77 \\
$\mathrm{Na}_{2} \mathrm{O}$ & 3.00 & 3.35 \\
$\mathrm{~K}_{2} \mathrm{O}$ & 2.42 & 1.82 \\
$\mathrm{H}_{2} \mathrm{O}$ & 0.87 & 3.64 \\
$\mathrm{H}_{2} \mathrm{O}-$ & 0.53 & 0.42 \\
$\mathrm{P}_{2} \mathrm{O}_{5}$ & 0.18 & 0.25 \\
$\mathrm{CO}_{2}$ & 1.66 & - \\
\hline Tota] & 99.57 & 100.01 \\
\hline
\end{tabular}

1: Garnet biotite andesite from the Nijo-san district (after Morimoto, Fuzita and $\mathrm{Ka}$ sama, 1957).

2: Hornblende hypersthene andesite from the Amataki-yama district (after Kozu and Yagi, 1941). 
and corundum as the xenocryst. There are two types of phenocrystic garnets. One is fibrolite-bearing garnet and the other is a euhedral clear one.

The xenolith-bearing hornblende hypersthene andesite lava of the Amataki-yama district is composed of phenocrystic plagioclase $(\mathrm{An}=30-50)$, biotite, hornblende, hypersthene, garnet and augite, and its groundmass minerals are hypersthene, plagioclase, alkali feldspar, iron ores, apatite, crisotbalite and glass. The andesite includes garnet, staurolite, biotite, spinel, plagioclase and quartz as the xenocryst.

The chemical compositions of the garnet biotite andesite from Nijo-san district (Morimoto, Fuzita and Kasama, 1957) and of the hornblende hypersthene andesite from the Amataki-yama district (Kozu and Yagi, 1941) are shown in Table 1. The garnet biotite andesite is richer in $\mathrm{SiO}_{2}$ and poorer in (total $\mathrm{FeO}+\mathrm{MgO}$ ) than the hornblende hypersthene andesite.

\section{Determination of Mineral Para- GENESES IN XENOLITHS}

It is supposed that the xenoliths in the volcanic rocks were intensely affected by magmatic heat and that they had very high thermal gradient for a relatively short period of time. Some mass transfer is also expected to occur between the xenolith and magma. Under these conditions, the metamorphic reaction does not reach equilibrium completely, metastable minerals usually appear and metasomatic zonation is sometimes produced in the xenoliths. Therefore, much caution is neccessary to decide the mineral parageneses of the xenoliths.

The mineral parageneses were determined by the coexistence of each mineral with a crystallographically concordant form in addition to their concomitance within the radius of about $1 \mathrm{~mm}$. Fibrous crystals were judged to associate stably with needle and symplectitic crystals, not columnar and granular ones. When both of columnar and/or granular crystals were euhedral or anhedral together, they were regarded as to be of paragenetic relation.

Furthermore, supposing that each part of the xenolith consists of constant inert components and perfectly mobile components through all stages of metamorphism, the mineral assemblages can be correlated with the mineral facies.

\section{DESGRIPTION OF THE NIJO-SAN XENOLITHS}

The argillaceous xenoliths of the Nijosan district are about $15 \mathrm{~cm}$ long, $10 \mathrm{~cm}$ broad and $5 \mathrm{~cm}$ thick in maximum, and their arrangement is concordant with the flow structure of the andesite lava. As the xenoliths sometimes show banding and gneissose structures, their original rocks are probably sedimentary rocks or pelitic schists. Most of the xenoliths, however show no schistosity. The metasomatic zonation appears rarely in the xenoliths. The grain-size of the xenoliths is usually medium and very rarely coarse. Porphyroblasts of andalusite, sillimanite, cordierite and garnet in them are commonly grains about $1 \mathrm{~mm}$ in diameter. All argillaceous xenoliths contain much calcic plagioclase, graphite and iron ores. Calcic plagioclase fairly euhedral, showing remarkable zonal structure and contains glass.

A coarse-grained quartzite is also found in the Nijo-san district.

There are three types of argillaceous xenoliths from this district. The type A 


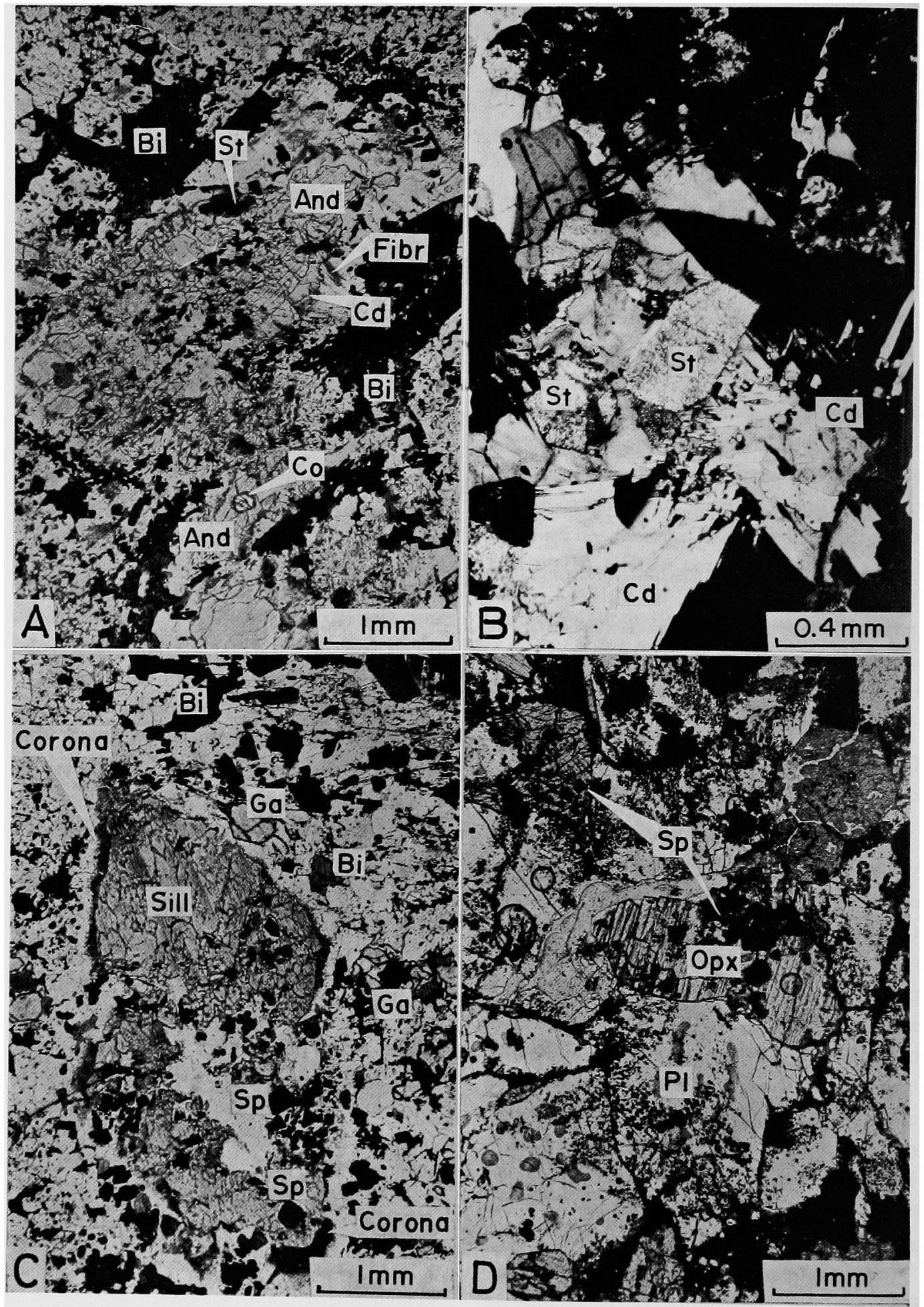




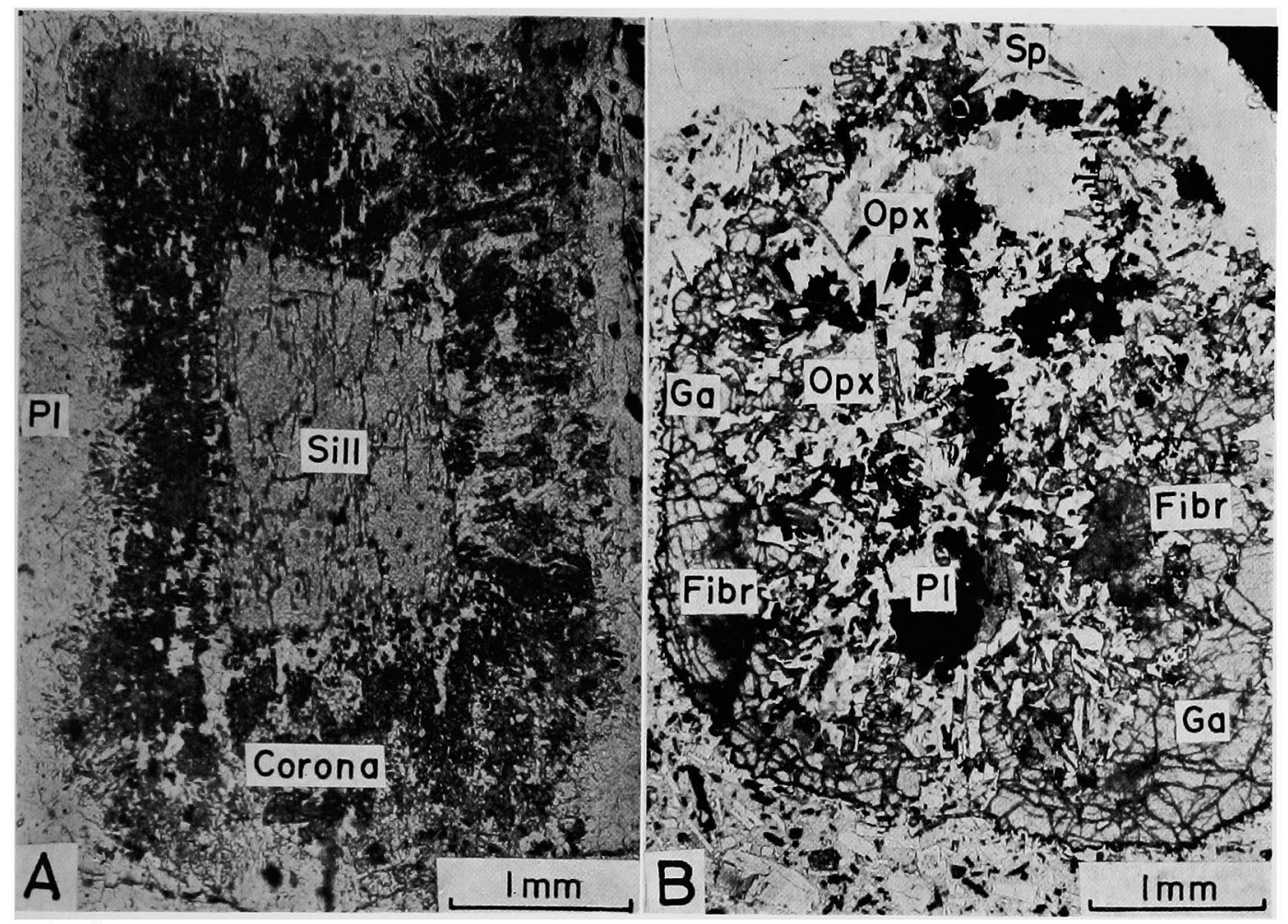

Fig. 3. Photomicrographs of the paragenetic relations (II).

A: The Corona texture of spinel-corundum-glass around sillimanite porphyroblast, the Nijo-san xenolith (plane polarized light).

B: The breakdown products of garnet, namely orthopyroxene-fibrolite-spinel, the Amatakiyama xenolith (plane polarized light)

Abbreviations as in Fig. 2.

lacks quartz, type B is quartz- and biotitefree, and type $\mathrm{C}$ contains quartz. The type $\mathrm{A}$ is most abundant among these xenoliths. Coarse-grained equigranular aggregates of quartz very rarely surrounds the quarzt-free xenoliths. In the collection there is only one specimen, exceptionally a large lump (about $5 \times 5 \times 5 \mathrm{~cm}$ ), of type $\mathrm{B}$ xenolith.

\section{Mineral Assemblages of Type A Xenolith}

This type consists of eight mineral assemblages as follow. For convenience such common minerals as plagioclase,

Fig. 2. Photomicrographs of the paragenetic relations (I).

A: The mineral assemblages of andalusite-staurolite-corundum and andalusite-staurolitecordierite (plane polarized light).

B: Staurolite crosses the twin boundary of cordierite (crossed polars).

C: The mineral assemblages of sillimanite-spinel-garnet and the corona texture of spinelcorundum-glass (plane polarized light).

D: The mineral assemblage of orthopyroxene-reddish spinel (plane polarized light).

All are the Nijo-san xenoliths.

Abbreviations are as follows: And : andalusite, $\mathrm{Bi}$ : biotite, Cd : cordierite, Co : Corundum, Fibr: fibrolite, Ga: garnet, Opx: orthopyroxene, Pl: plagioclase, Sill: sillimanite, Sp: Spinel. 
graphite, biotite and iron ores are omitted from the description of the assemblages.

1) Andalusite-staurolite-cordierite (Fig. 2A)

2) Andalusite-staurolite-garnet

3) Andalusite-staurolite-corundum

(Fig.

2A)

4) Andalusite-staurolite-spinel

5) Sillimanite-spinel-corundum ( + metastable andalusite)

6) Sillimanite-garnet-cordierite

7) Sillimanite-garnet-spinel (Fig. 2C)

8) Fibrolite-corona spinel-corona corundum-glass (Fig. 2C)

Andalusite is subhedral porphyroblast, and has a zonal structure as shown by the shades of reddish pleochroism. Staurolite is subhedral, shows a golden yellow pleochroism and does not associate with sillimanite. Sometimes the staurolite crystals cross the twin boundary of cordierite (Fig. 2B). Cordierite is porphyroblast and shows pale bluish pleochroism. The distortion index and the optic axial angle of a cordierite $(\gamma=1.544$ and $\alpha=1.534)$ is 0.28 and $45^{\circ} \pm 5^{\circ}$, respectively. Garnet is subhedral to euhedral and rich in almandine molecules. Spinel occurs as subhedral to euhedral crystals with green color. Corundum is subhedral to anhedral and blue in color. Sillimanite occurs as porphyroblast, and frequently coexists with metastable andalusite. Fibrolite grows in the crystals of plagioclase, cordierite, garnet and staurolite. The X-ray powder patterns of the fibrolite are those of sillimanite. Therefore, fibrolite is the fine needles of sillimanite and easily distinguished from sillimanite described here by the differences of grain-size and crystal habit in the Nijosan xenoliths.

The mineral assemblages 1)-4) do not coexist stably with those of 5)-7) in a xenolith. The mineral assemblage 8) showing corona texture occurs around andalusite, sillimanite and staurolite (Fig. 3A).

Mineral Assemblage of Type B Xenolith

The mineral assemblage of this type is as follow.

1) orthopyroxene-spinel-plagioclase-olivinecordierite (Fig. 2D)

Because this massive xenolith is very coarse-grained equigranualr in texture, the criteria for determination of the mineral paragenesis mentioned above does not apply to it. The zonal structure of plagioclase is not remarkable. The xenolith contains much graphite. Most of the iron ores are ilmenite. Orthopyroxene shows weak pleochroism and its optic axial angle is (-) $56^{\circ} \pm 5^{\circ}$. Spinel is purplish red in color $(a=8.13)$. Cordierite and olivine are rare.

\section{Mineral Assemblage of Type $C$ Xenoliths}

All specimens of this type have the following single mineral assemblage.

1) Biotite - plagioclase - garnet - quartziron ores-graphite土alumino silicate.

\section{DESGRiption OF THE AMATAKI-YAMA XeNOLITHS}

The xenoliths of the Amataki-yama district are much smaller than those of the Nijo-san district. These xenoliths also show a banding structure, and their grainsize are usually medium and rarely coarse. Porphyroblasts are not sillimanite and cordierite, but garnet and staurolite. Sillimanite crystals are fibrous or fine needles. All xenoliths contain calcic plagioclase, graphite, biotite and iron ores, and lack quartz as in the case of type A of the Nijosan xenoliths. Biotite, staurolite, garnet 
and spinel frequently have a opacite margin. These xenoliths consist of five mineral assemblages as follow. The common minals of all assemblages, that is, plagioclase, biotite, graphite and iron ores, are omitted from the descriptions.

1) Staurolite-spinel-cordierite

2) Staurolite-spinel-garnet

3) Fibrous sillimanite-spinel-garnet

4) Orthopyroxene-fibrolite-spinel (Fig. 3B)

5) Fibrolite-corona spinel-corona corundum.

In the Amataki-yama xenoliths, all staurolites associate with spinel in contrast with the staurolite-bearing mineral assemblages of the Nijo-san xenoliths. The modal content of staurolite in the Amatakiyama xenoliths are more than those of the Nijo-san ones. Garnet including both staurolite and spinel occurs occasionally (Takeuchi, 1941). The mineral assemblage
4) is the breakdown product of garnet, and the grain-size of each mineral is very fine. Orthopyroxene shows pale greenish pleochroism and has a small optic axial angle $\left(-51^{\circ} \pm 5^{\circ}\right)$. The corona texture of the mineral assemblage 5) appears around staurolite and garnet, and consists mostly of spinel. Corundum in this assemblage is very rare.

\section{Mineral Paragenetic Relations of THe Quartz-Free Xenoliths}

Since staurolite forms over a wide range of rock-pressure, it is able to occur not only in regional metamorphic terranes but also in contact aureoles. From the texural relations the staurolite crystals in the xenoliths in question do not appear to be the relic of the product by older regional metamorphism. All of the observed minerals and textures of the xenoliths were

\section{Contact Metarnorphism}
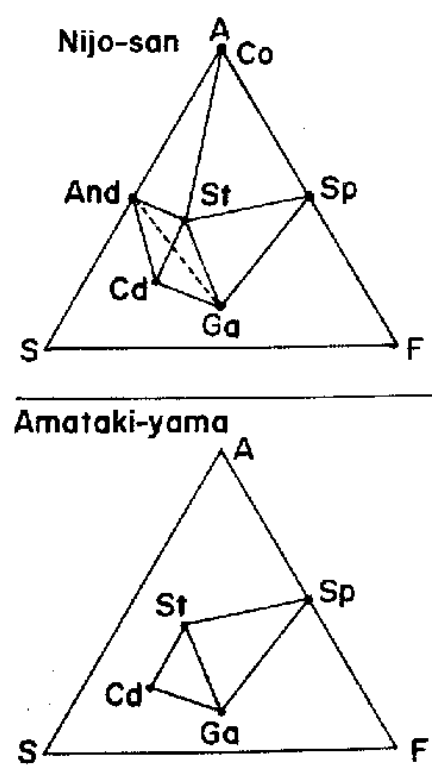
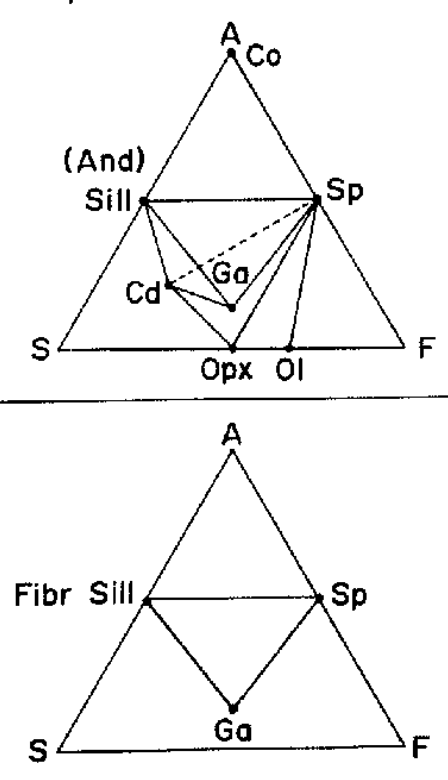

\section{Pyrometamorphism}

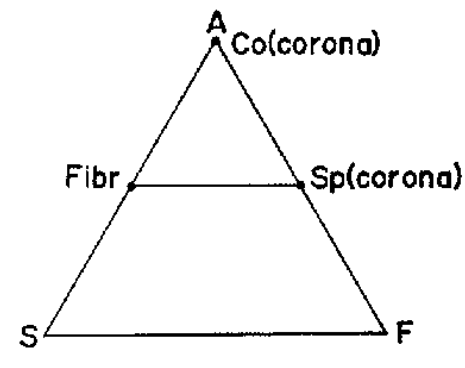

Fig. 4. The $\mathrm{Al}_{2} \mathrm{O}_{3}-(\mathrm{FeO}+\mathrm{MgO})-\mathrm{SiO}_{2}$ diagram.

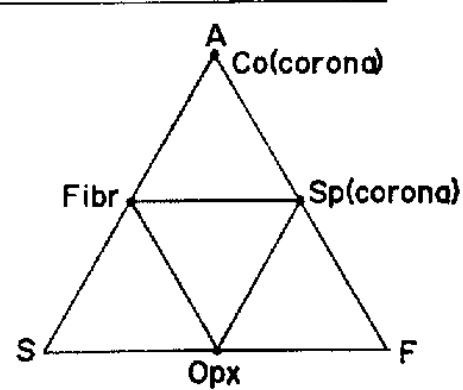
A: $\mathrm{Al}_{2} \mathrm{O}_{3}, \mathrm{~S}: \mathrm{SiO}_{2}, \mathrm{~F}:(\mathrm{FeO}+\mathrm{MgO})$. Other abbreviations as in Fig. 2. 
probably the result of the younger thermal metamorphism alone, if these xenoliths had formerly suffered regional metamorphism.

The paragenetic relations of the minerals of the quartz-free xenoliths can be represented in the triangular diagram of $\mathrm{Al}_{2} \mathrm{O}_{3}-(\mathrm{FeO}+\mathrm{MgO})-\mathrm{SiO}_{2}$ system. All minerals except those of the excess and indifferent components in these xenoliths appear in this system. Orthopyroxene, red spinel, olivine and cordierite are probably so rich in $\mathrm{MgO}$ that system $\mathrm{Al}_{2} \mathrm{O}_{3}-(\mathrm{FeO}+\mathrm{MgO})-$ $\mathrm{SiO}_{2}$ admits tie-line showing tetragon. The corona texture of spinel-corundumglass surrounding sillimanite is evidence that the $\mathrm{SiO}_{2}$ component becomes a perfectly mobile one at the last stage of metamorphism, still this triangular diagram is applicable on these parageneses. The $\mathrm{Al}_{2}$ $\mathrm{O}_{3}-(\mathrm{FeO}+\mathrm{MgO})-\mathrm{SiO}_{2}$ diagrams, though they are not complete, are shown in Fig. 4.

The mineral assemblages of these xenoliths are divided into the following two groups in terms of grain-size which is clearly different between the two: one group is of the large-grained minerals and the other those of the fine-grained minerals. Furthermore, the former is subdivided into the staurolite-bearing parageneses and the staurolite-free ones. In the Nijo-san district, the type $B$ xenolith is probably so rich in $\mathrm{MgO}$ that its paragenetic plane does not join any planes of the staurolite-free parageneses of type A. The staurolitebearing, aluminous xenoliths are lacking in the Amataki-yama district.

As mentioned above, staurolite may not be a relic of older regional metamorphism, and practically it associates with some minerals according to the mineralogical phase rule. Therefore, it can be emphasized that those xenoliths recrystallized succe- ssively with increasing temperature of the thermal metamorphism caused by the andesitic magma.

The staurolite-bearing parageneses can be regarded as the amphibolite facies or the pyroxene hornfels facies. The staurolitefree parageneses including the orthopyroxenespinel-olivine-cordierite assemblage belong to the pyroxene hornfels facies (Chinner, 1962). The corona texture of spinel-corundum-glass and the breakdown products of garnet, namely, orthopyroxene-fibrolite-spinel indicate that the parageneses of the fine-grained minerals were formed under the conditions of the pyroxene hornfels or the sanidinite facies (Smith, 1969). From the experiments by Richardson (1968) and Ganguly (1972), the staurolite-bearing

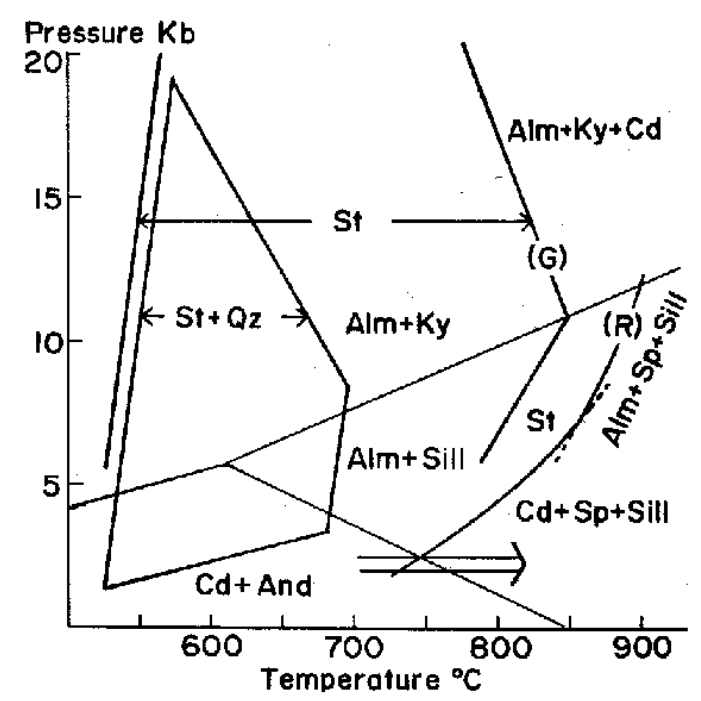

Fig. 5. P-T projections of eqilibria defining the limits of thermal stability of staurolite + quartz, at oxygen fugacities around the middle of the magmatic field of Ganguly (1972). The alumino silicate equilibria stands for Richardson, Bell and Gilbert (1969), (R) for Richardson (1968) and (G) for Ganguly (1972). The arrow shows the approximate conditions of this thermal metamorphism. Alm: almandine, $Q z$ : quartz. Other abbreviations as in Fig. 2. 
quartz-free xenoliths recrystallized at a temperature below $750^{\circ} \mathrm{C}$ and at about 2 $\mathrm{Kb}$ (Fig. 5).

With increasing temperature, staurolite disappears and andalusite transforms into sillimanite. The association of sillimanite and the imcompatibility of staurolite and sillimanite indicate a nearly constant pressure through the metamorphism. With further increasing of temperature, garnet decomposes to orthopyroxene, spinel and fibrolite. At the same time, sillimanite, metastable andalusite and staurolite react to the andesitic magma to form the corona texture of spinel-corundum-glass. In the metasomatic parts, which are 5-10 $\mathrm{mm}$ wide from the contact with the andesite, sillimanite prophyroblast is completely replaced with corundum mantled by spinel, and plagioclase becomes extremely euhedral. At the highest grade, the xenoliths in the magma become desilicified and partially melted. Consequently, the original mineral assemblages of the xenoliths become completely reconstructed during the thermal metamorphism by the andesitic magma, if they had suffered older regional metamorphism.

The difference of the staurolite-bearing assemblages between the Nijo-san and Amataki-yama xenoliths is probably caused by the difference of the original rocks and/or by the different degrees of the metasomatic reaction, especially desilicification, between the xenolith and the magma.

It is supposed that the xenoliths of the two districts first suffered contact metamorphism at the wall rocks of the magma chamber or of conduit for the rising andesitic magma, and then were intensely affected by magmatic heat as inclusions in the magma. From the progressive change of mineral facies and the distinct descrep- ancy of grain-size between the large mineral assemblages and fine grained ones, it is possible to consider, roughly estimating, that the former indicates the stage of contact metamorphism and the latter shows that of pyrometamorphism in the andesitic magma.

The mineralogy and petrochemistry of these xenoliths will be reported at another oppotunity.

\section{AGKNOWLEDGEMENTS}

The authors would like to express their gratitude to Professor Emeritus Kotora Hatai of the Tohoku University for critical reading of the manuscript, and to Professor Yoshio Ueda of the Tohoku University for his constant encouragment. Thanks also due to Drs. Iwao Kato, Hiromitsu Taniguchi of the Science Education Institute of Osaka Prefecture, Dr. Jo Taniyama of the Kagawa University and Dr. Osamu Ujike of the Geological Survey of Japan for supplying the samples.

\section{REFERENGES}

Asami, M. (1971), Finding of staurolite-bearing pelitic schist in the Ryoke metamorphic belt of central Japan. Proc. Japan Acad., 47, 511516.

Chinner, G.A. (1962), Almandine in thermal aureoles. Jour. Petrol., 3, 316-340.

Ganguly. J. (1968), Analysis of the stabilities of chloritoid and staurolite and some eqilibria in the system $\mathrm{FeO}-\mathrm{Al}_{2} \mathrm{O}_{3}-\mathrm{SiO}_{2}-\mathrm{H}_{2} \mathrm{O}-\mathrm{O}_{2}$. Amer. Jour. Sci., 266, 277-298.

- (1972), Staurolite stability and related parageneses: Theory, experiments, and applications. Jour. Petrol., 13, 335-365.

Ishioka, K. and Suwa, K. (1956), Metamorphic development of staurolite schist from rhyolite on the Kurobe-gawa area, central Japan, a preliminary report. Jour. Earth Sci. Nagoya Univ., 4, 123-140.

Kato, I., Muroi, I., Yamazaki, T. and Abe, M. (1971), Subaqueous pyroclastic flow deposits in the upper Donzurubo formation, Nijo-san 
district, Osaka, Japan. Jour. Geol. Soc. Japan, 77, 193-206.

Kozu, S. and Yagi, K. (1941), Chemical studies of garnet and its mother rock from Amataki. Jour. Japan. Assoc. Min. Petrol, Econ. Geal,, 26, 101-121 (in Japanese with English abstract).

Miyashiro, A. (1965), Metamorphic rocks and metamorphic belts. Iwanami Pub., Tokyo (in Japanese).

Morimoto, R., Fuzita, K., Yoshida, H., Matsumoto, T. Ichikawa, M., and Kasama, T. (1953), Geology of the Nijo-san district. Earth Science (Chikyu Kagaku), 11, 1-12 (in Japanese).

- - and Kasama, T. (1957), Cenozoic volcanism in southwestern Japan with special reference to the history of the Setouchi (Inland Sea) geologic province. Bull. Earthq. Res. Inst. Tokyo Univ., 35. 35-45.

Research Group of the Abukuma Plateau (1969), Polymetamorphism in the Abukuma Plateau with special regards to the discovery of staurolite and kyanite. Mem. Geol. Soc. Japan, No. 4, 83-97 (in Japanese with English abstract).

Richardson, S. (1968), Staurolite stability in a part of the system Fe-AI-Si-O-H. Jour. Petrol., 9, $467-488$.

, Bell, P.M. and Gilbert, M.C. (1969), Experimental determination of kyaniteandalusite and andalusite-sillimanite equilibria; aluminous silicate tripple point. Amer. Jour. Sci, 267, 259-272.

Smith, D.G.W. (1969), Pyrometamorphism of phyllites by a dolerite plug. Jour. Petrol., 10, 20-55.

Tagiri, M. (1971) Metamorphic rocks of the Hitachi district in the southern. Abulkuma Plateau. Jour. Japar. Assoc. Min. Petrol. Econ. Geol., 65, 77-103.

Takeuchi, T. (1941), Studies of garnet and of its country rock from Amatalki. Jour. Japan. Assoc. Min. Petrol. Econ. Geol., $51-60$ (in Japanese with English abstract).

Ujike, O. (1972), Petrology of Tertiary calc-alkaline volcanic rock suite from northeastern Shikoku and Shodo-shima island, Japan. Sai. Rep. Tohaku Univ., Ser. III, 11, 159-209.

Uruno, K. and Kanisawa, S. (1965), Staurolitebearing rocks in the Abukuma metamorphic belt, Japan. Eavth Science (Chihys Kagaku), 81, 1-12.

Yamazaki, T. and Onuki, H. (1969), Differentiation of the calc-alkaline magma at Nijo-san district, Osaka. Jouv. Japan. Assoc. Min. Petrol. Econ. Geol., 62, 249-263 (in Japanese with English abstract).

-, Kato, I., Muroi, I. and Abe, M. (1973), Textural analysis and flow mechanism of the Donzurubo subaqueous pyroclastic flow deposits. Bull. Volcan., Ser. 2, 37, 231-244.

\title{
二上山および雨滰山産安山岩啠岩石中の粘土翼捕獲岩類の鉱物共生
}

\author{
田切美智雄・大貫化山㱦 貞 治
}

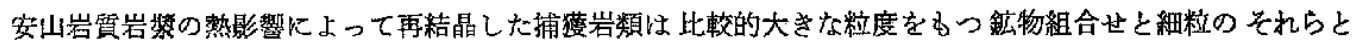

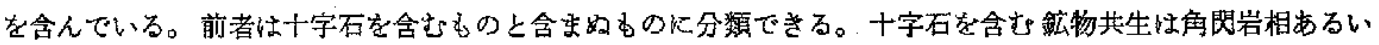

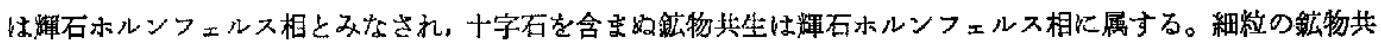
生であるコロナ組繀やざくろ石の分解生成物は輝石ホルンフェルス相あるいはサニディナイト相の条件下で形 成された。捈物相の增進的変化や 2 種の粒度の差のはっきりした鉣物共生の存在から，比較的大きな鉱物共生関 係㢺触变成作用にて，細粒の钩物共生関係はパイロ变成作用の結果であると考えることが可能である。

$$
\text { Nijo-san 二上山 Amataki-yama 雨滝山 }
$$

